\title{
FAILURE OF RESERPINE TO PRODUCE CHANGES IN THE STORE OF PITUITARY GONADOTROPHINS IN THE COCKEREL
}

\author{
REMO B. REDELONGHI, S. J. TRUMPER AND R. A. BOSGH \\ Universidad Nacional de La Plata, Facultad de Ciencias Veterinarias, \\ Laboratorio de Histología, 60 y 118, La Plata, Argentina
}

(Received 27th February 1970)

There is some evidence that reserpine produces alteration of pituitary and testicular function in birds (Assenmacher, Tixier-Vidal \& Baylé, 1961; TixierVidal \& Assenmacher, 1962). Hagen \& Wallace (1960), working with cockerels, found that the testicular weight was reduced by half. However, very little is known about the effect of reserpine on the content of gonadotrophins in the pituitary of birds. The following experiment was conducted to investigate the total pituitary gonadotrophic potency in cockerels treated with reserpine.

The birds used were White Leghorn cockerels aged 100 days and weighing between 1.5 and $1.8 \mathrm{~kg}$. They were kept on a lighting schedule of $14 \mathrm{hr}$ light/ $10 \mathrm{hr}$ dark and had free access to food and water. The reserpine (Serpasol, Ciba) was injected into the breast muscle at a dose of $250 \mu \mathrm{g} / \mathrm{animal}$ (about $16 \mu \mathrm{g} / 100 \mathrm{~g}$ body weight) for 25 days. Previous trials demonstrated that higher doses ( 400 to $500 \mu \mathrm{g} /$ animal) caused a significant decrease in food intake. The control group received saline in equal volume. All the birds were weighed and killed by decapitation $24 \mathrm{hr}$ after the last injection. The testes were weighed and the anterior pituitaries were removed and immediately placed in acetone for $60 \mathrm{hr}$. After storage in a desiccator at room temperature for a week, the pituitaries were ground and the dried powder was kept in the desiccator until ready for use. One $\mathrm{mg}$ of the powder was suspended in $1.0 \mathrm{ml}$ of distilled water immediately before use. The total pituitary gonadotrophins were assayed by the testicular weight augmentation method, using baby cockerels, according to the method of Breneman (1945), modified by Nakajo \& Imai (1956).

The results of this experiment are summarized in Table 1 . They suggest that chronic administration of reserpine does not alter the content of gonadotrophins in the pituitary. Labhsetwar (1967) found a decrease in the LH pituitary stores and a significant increase in the FSH stores in female rats given prolonged treatment with reserpine, but our assay was not designed to test this differentiation.

Reserpine did not affect testicular growth in the present experiments. This finding contrasts with the results of Hagen \& Wallace (1960) who found a marked reduction in testis weight after giving doses of between 1 and $4 \mathrm{mg} / \mathrm{kg}$ weekly for 10 weeks, though these authors gave doses that were higher than 


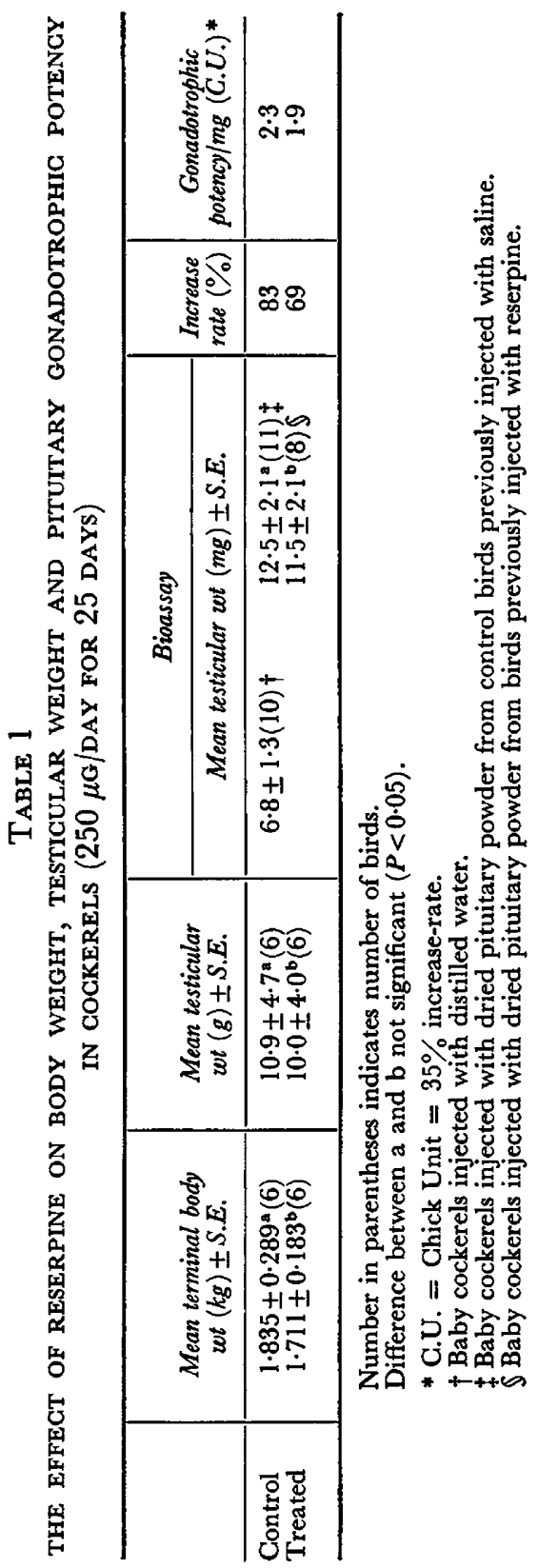


those used in the present experiment and above the level which caused a decrease in food intake in preliminary trials. Gaunt, Renzi, Antonchak, Miller \& Gilman (1954) stated that when reserpine is given in doses which produce inanition and body weight loss, it can deplete androgen secretion by indirect means.

Further investigations will be necessary to elucidate this interesting fact.

We are grateful to Molinos Río de La Plata and Arbor Acres Argentina for furnishing materials and to the Comisión de Investigaciones Científicas de la Universidad Nacional de la Plata for the financial support.

\section{REFERENCES}

Assenmacher, I., Tixier-Vidal, A. \& Baylé, J. D. (1961) Inhibition du réflexe photo-sexuel par la réserpine chez le canard mâle. C. r. Séanc. Soc. Biol. 155, 2235.

BRENEMAN, W. R. (1945) The gonadotropic activity of the anterior pituitary of cockerels. Endocrinology, 36, 190.

Gaunt, R., Renzi, A. A., Antonchak, N., Mrller, G. J. \& Gilman, M. (1954) Endocrine aspects of the pharmacology of reserpine. Ann. N.Y. Acad. Sci. 59, 22.

Hagen, P. \& Wallace, A. (1960) An effect of reserpine on growth and sexual maturation. Fedn Proc. Fedn Am. Socs exp. Biol. 19, 168.

LABHSETWAR, A. P. (1967) Differential effects of reserpine on pituitary luteinizing hormone and follicle-stimulating hormone level in the female rat. Endocrinology, 81, 357.

NAKajo, S. \& Imal, K. (1956) Investigation on chick assay method for avian gonadotrophins. Endocr. jap. 3, 197.

Trxier-Vidal, A. \& Assenmacher, I. (1962) Effets d'un traitement isolé ou combiné a la réserpine et à la lumière permanente sur la préhypophyse du canard mâle. C. r. Séanc. Soc, Biol. 156, 37. 